\title{
Storytelling using MAIN in Yakut
}

\section{Yulia Androsova}

Research Institute of National Schools of the Republic of Sakha, Russia

\author{
Aleksandra Trifonova
}

Universität Potsdam

This paper describes the process of adapting the Multilingual Assessment Instrument for Narratives (LITMUS-MAIN) to Yakut. A brief description of the Yakut language and its status in Russia is given after which the use of the Yakut version of MAIN in the Republic of Sakha (Russia) is described.

\section{Introduction and the context in which Yakut is spoken}

The system of preschool and general education in the Sakha Republic includes the following forms of bilingual education: 1) the native language Yakut as the language of instruction in primary schools with subsequent transition to Russian; 2) Russian as the language of instruction and Yakut as a school subject (Androsova, 2019). However, internal migration has led to a massive resettlement of members of the rural population to the bigger cities, where education institutions do not have the appropriate level of expertise in educating children in Yakut (Androsova, 2019).

The Republic of Sakha, also called Yakutia (yakut. Саха ӨрөспүҮбүлүкэтэ, Саха Сирэ), is one of the 85 multi-ethnic federal states of Russia. Yakutia occupies over 3 million $\mathrm{km}^{2}$ and has a population of one million people (The Federal Agency for Tourism of the Russian Federation). Yakut is spoken by 450,140 people in Russia, 441,536 of whom live in the Sakha Republic (Ferguson, 2016). According to the All-Russian Population Census (2010), over 130 ethnic groups live in Yakutia.

Yakutia has two official languages, Russian and Sakha, as well as five minority languages: Even, Evenki, Yukaghir, Chukchi and Dolgan. The Sakha language has a standardized written language and is broadly used in culture, education, mass media, in the work of state organizations, and public organizations in the republic (Androsova, 2019). The majority of the Yakuts, with the exception of the elderly who live in monolingual rural areas, 
are bilingual speakers of their native language Yakut and Russian: 89\% of the population in Yakutia are reported to be bilingual (Androsova, 2019; Ferguson, 2016). Moreover, linguistic and cultural diversity in Yakutia is protected by federal and regional laws, mainly by the state program "Preservation, study and development of state and official languages in the Republic of Sakha (Yakutia)" (The Government of the Republic of Sakha, 2019).

Nowadays, due to globalization processes, the language environment has changed even in monolingual communities in Yakutia. A recent research project, carried out by the Research Institute of National Schools of the Republic of Sakha (Yakutia), revealed a general decline in native language proficiency of Yakut children aged 5-9, and a prevalence of the use of Russian in informal communication and play activities (Androsova, 2016). The knowledge of the native language Yakut is decreasing in the population more generally, the number of children with speech problems is increasing, a mixed Yakut-Russian speech variety is becoming the norm even in adults, and the number of preschool age children who do not know their native language is also increasing (Androsova, 2018). In 1998, every fourth child from a Yakut family living in a city did not speak his/her native language (Robbek, 1998). However, families, in which neither the parents nor the grandparents can pass on their native language to their children and grandchildren, choose for their children to attend nurseries which have Yakut as the medium of education in the hope that their children will learn their native language there (Androsova, 2019).

\section{A brief overview of the Yakut language}

The Yakut language (саха тылла), which is also known as Sakha, is a member of the Northern group of the Siberian-Turkic branch of the Turkic languages (Ivanova et al., 2019). A brief description of the Yakut grammar is presented below.

In terms of phonology, as is typical in Turkic languages, vowel harmony is attested in Yakut. This means that, first, front and back vowels never appear within one word, and second, that vowels in the following syllables have to harmonize with those in the antecedent syllables (Ebata, 2012). Further, palato-velar and labial vowel harmony are differentiated (Ivanova et al., 2019).

Morphologically, Yakut is an agglutinative language (Ebata, 2014). In terms of word formation, Yakut makes an extensive use of suffixation (Ebata, 2012). Case agreement is characterized as dependent-marking, meaning that case is expressed by the attachment of case suffixes to NPs. However, while possessive suffixes are attached to the possessed NPs, the possessor NPs do not receive any morphological marking (Head-marking) (Ebata, 2012). In addition, Yakut has an exceptionally high number of verbal tenses. The main tenses are proximal-past, remote-past, past perfect, episodic past, past imperfect, pluperfect, episodic pluperfect (Ivanova et al., 2019).

With respect to syntax, Yakut has a basic SOV word order (Ebata, 2014). However, the word order is not strict and can be alternated or inverted leading to a shift in the meaning of the sentence. The basic word order pattern also receives support from the morphology, although 
not all sentence components may display overt morphological features; in this case, the word order plays a crucial role in understanding a sentence (Čeremisina, 1995). When it comes to syntactic derivation, which is quite prominent in Yakut, this process is reported to have a crosslinguistically unique feature: the base verb valency is retained after the nominalization process, leading to a "mismatch" between syntax and morphology (Ebata, 2012; Ebata, 2020). In contrast to English, there are instances of Yakut deverbal derivation where the base preserves its verbal property, namely, government. For example, in kinige-niaas-aačcï 'book reader' (lit. 'read a booker'), after the derivational process has taken place, the verb stem is still able to assign the accusative case to the noun (Ebata, 2020, p. 8). Furthermore, various sources of syntactic derivation have been reported for Yakut: noun phrases containing modification, whquestions, total negation, which constitute a counter-argument for the lexical integrity hypothesis (Ebata, 2020 for discussion). Another unique property of Yakut is the doubleaccusative causatives, which are virtually impossible in other Turkic languages (Ebata, 2013). In addition, impersonal passives derived from transitive and intransitive clauses are found in Yakut (Ebata, 2013).

\section{Adapting MAIN to Yakut}

The problem of teasing apart developmental language disorders and the specifics of bilingual language acquisition has been addressed extensively in previous research (Gillam et al., 2013; Grimm \& Schulz, 2014; Paradis, 2010). The need for appropriate linguistic assessment tools for minority languages has also been pointed out (Fleckstein et al., 2018). One tool that addresses this problem is the Multilingual Assessment Instrument for Narratives (MAIN; Gagarina et al., 2012, 2015, 2019), which belongs to the language test battery Language Impairment Testing in Multilingual Settings (LITMUS) (Armon-Lotem et al., 2015). The MAIN is a tool which allows for the narrative skills assessment in children acquiring one or more languages. It includes four parallel testing stories accompanied by a picture-sequence that can be used in three elicitation modes, telling, retelling, model story (Gagarina et al., 2012). In what follows, the process of adapting MAIN to Yakut is described.

As has been previously pointed out in Peña (2007), not only linguistic equivalence should be ensured in the process of translation of assessment instruments and their instructions, but also the functional equivalence, cultural equivalence and metric equivalence. These recommendations have been taken into consideration and implemented during the process of adapting MAIN to Yakut. The guidelines for adapting MAIN to new languages (Bohnacker \& Gagarina, 2019) were followed closely. At the first stage of the adaptation process, the materials were translated to Yakut by the first author, Yulia Androsova, a researcher at the Research Institute of National Schools (Yakutsk, Russia). After the translation process was completed, a pilot testing (see Section 4) was conducted in collaboration with Ainara Sokolnikova, a child psychologist. A number of modifications to the translation of two stories were undertaken after the pilot testing. Finally, the Yakut MAIN was checked by linguists from the Research Institute 
of National Schools to ensure that it was in accordance with the revised English MAIN (Gagarina et al., 2019).

During the translation process, some difficulties occurred with respect to finding the appropriate equivalents of some adjectives, such as 'playful' and 'cheerful'. This was due to the fact that these words are expressed with rather complicated constructions in Yakut, which might be challenging for young children to understand. Therefore, the adjective 'playful' was translated as мэник-мэнигийээн (menik-menigijeen 'frolicsome'), which generally conveys the same meaning as 'playful'. The adjective 'cheerful' was translated as yөрбүт-көппүт (yerbytkeppyt, 'joyful'). The rest of the linguistic structures did not cause much difficulty for translation.

All stories were translated at the level most accessible for children, i.e. without using complex constructions that might be unknown to or infrequently used by children. The content of all stories and their characters were found to be suitable for the culture and daily life of Yakut children. The pilot study (see Section 4) showed that children did not have any difficulty in understanding the stories.

\section{$4 \quad$ Piloting the Yakut MAIN}

Thirty typically developing bilingual Yakut-Russian children aged 6-8 (20 boys and 10 girls) participated in the pilot testing of the Yakut version of MAIN. The analysis of the performance in Yakut and Russian revealed that while most of the stories in Yakut were very short and scanty, the children's performance on the Russian tasks turned out to be much better. The Yakut narratives usually began immediately with a goal and an attempt, without any spatial or temporal specification. Furthermore, only a limited number of internal state words was used in the Yakut narratives. In contrast, the Russian narratives were much more detailed and richer in terms of vocabulary use. Many children used internal state words in Russian that they did not use in their Yakut narratives. Also, all children showed good results with regard to narrative comprehension in Russian. In addition, the following information about the language use of the children in the study was obtained with the help of a parental questionnaire:

- $90.3 \%$ of the children attended kindergartens which had Yakut as the language of instruction.

- $45 \%$ of parents reported that they exclusively used Yakut in communication with their child; the remaining 55\% used both Russian and Yakut.

- $43 \%$ of parents indicated that, in most cases, the speech of their child would include a mixture of Russian and Yakut.

- For the majority of children (65\%), the onset of regular contact with the second language Russian began before age 3; 25\% came into regular contact with Russian only before age 5, whereas $10 \%$ were exposed to Russian already before age 1 .

- $48 \%$ of parents reported that their child had a "quite good" or "excellent" knowledge of both Yakut and Russian. 
- $52 \%$ of parents reported that their child had a preference for using Russian.

\section{Conclusion}

MAIN has been adapted to Yakut and piloted by a group of Russian researchers in the Republic of Sakha (Yakutia). The adaptation process was based on the revised English version of MAIN (Gagarina et al., 2019) and was carried out in accordance with the procedure for adapting MAIN to new languages (Bohnacker \& Gagarina, 2019). The MAIN is proving to be a useful diagnostic tool for the Yakut language. The researchers at the Research Institute of National Schools of the Republic of Sakha (Russia) are planning to receive an official approval for the use of MAIN and apply it in their research on bilingual child language acquisition. In addition, MAIN is planned to be used for individual work with bilingual children and their parents at education centers for preschool and junior school children in the Republic of Sakha (Russia).

\section{$6 \quad$ References}

All-Russian Population Census (2010). https://www.gks.ru/. Accessed on 17 June 2020.

Androsova, Y. (2016). Модель психолого-педагогического сопровождения билингвального образовательного процесса. [A model of psychological and pedagogical support of the bilingual educational process]. Nauchnoe mnenie, 16, 126-130.

Androsova, Y. (2018). Игровые предпочтения детей дошкольного возраста в билингвальной среде. [Game preferences of pre-school children in a bilingual environment]. Modern Studies of Social Issues, 9(12), 618.

Androsova, Y. (2019). Модель развития национально-русского двуязычия у детей через игровую деятельность. [The development model of national-Russian bilingualism in children through play activities]. World of Science. Pedagogy and psychology, 6(7).

Armon-Lotem, S., de Jong, J. \& Meir, N. (Eds.) (2015). Assessing multilingual children: Disentangling bilingualism from language impairment. Bristol, UK: Multilingual Matters.

Bohnacker, U. \& Gagarina, N. (2019). Background on MAIN - Revised, how to use it and adapt it to other languages. ZAS Papers in Linguistics, 63, iv-xii.

Čeremisina, M. I. et al. (Ed.). (1995). Грамматика современного якутского литературного языка. Синтаксис. [Grammar of the modern standard Yakut. Syntax]. Moscow: Nauka.

Ebata, F. (2012). Valency retention in Sakha derivational nominalization. Asian and African Languages and Linguistics, 13, 53-66.

Ebata, F. (2013). Causative and passive in Sakha: focusing on double-accusative causative and impersonal passive. Tomsk Journal of Linguistics and Anthropology, 2(2), 16-28.

Ebata, F. (2014). The Sakha proprietive suffix -leex. Tomsk Journal of Linguistics and Anthropology, 1(3), 2334.

Ebata, F. (2020). Agglutinativeness, Polysynthesis, and Syntactic Derivation in Northeastern Eurasian Languages. Northern Language Studies, 10, 1-16. 
Ferguson, J. (2016). Language Has a Spirit: Sakha (Yakut) Language Ideologies and Aesthetics of Sustenance. Arctic Anthropology, 53(1), 95-111.

Fleckstein, A., Prévost, P., Tuller, L., Sizaret, E. \& Zebib, R. (2018) How to identify SLI in bilingual children: A study on sentence repetition in French. Language Acquisition, 25(1), 85-101.

Gagarina, N., Klop, D., Kunnari, S., Tantele, K., Välimaa, T., Balčiūnienė, I., Bohnacker, U., \& Walters, J. (2012). MAIN: Multilingual Assessment Instrument for Narratives. ZAS Papers in Linguistics, 56.

Gagarina, N., Klop, D., Kunnari, S., Tantele, K., Välimaa, T., Balčiūnienė, I., Bohnacker, U., \& Walters, J. (2015). Assessment of Narrative Abilities in Bilingual Children. In S. Armon-Lotem, J. de Jong, \& N. Meir (Eds.), Assessing multilingual children disentangling bilingualism from language impairment (pp. 243-269). Bristol: Multilingual Matters.

Gagarina, N., Klop, D., Kunnari, S., Tantele, K., Välimaa, T., Bohnacker, U., \& Walters, J. (2019). MAIN: Multilingual Assessment Instrument for Narratives - Revised. ZAS Papers in Linguistics, 63.

Gillam, R. B., Peña, E. D., Bedore, L. M., Bohman, T. M., \& Mendez-Perez, A. (2013). Identification of specific language impairment in bilingual children: I. Assessment in English. Journal of speech, language, and hearing research, 56(6), 1813-1823.

Grimm, A., \& Schulz, P. (2014). Specific Language Impairment and Early Second Language Acquisition: The Risk of Over- and Underdiagnosis. Child Indicators Research, 7, 821-841.

Ivanova, S., Katinskaia, A., \& Yangarber, R. (2019). Tools for supporting language learning for Sakha. In M. Hartmann, \& B. Plank (Eds.), The Proceedings of the 22nd Nordic Conference on Computational Linguistics (NoDaLiDa) (pp. 155-163).

Paradis, J. 2010. Bilingual children's acquisition of English verb morphology: Effects of language exposure, structure complexity, and task type. Language Learning, 60, 651-680.

Peña, E. D. (2007). Lost in translation: Methodological considerations in cross-cultural research. Child development, 78, 1255-1264.

Robbek, V. (1998). Language Situation the Sakha Republic (Yakutia). Bicultural Education in the North: Ways of Preserving and Enhancing Indigenous Peoples' Languages and Traditional Knowledge. 113-122.

The Federal Agency for Tourism of the Russian Federation. (2020). www.russiatourism.ru. Accessed on 17 June 2020.

The Government of the Republic of Sakha. (2019). Указ Главы Республики Саха (Якутия) от 21 февраля 2019 г.№383 "Об утверждении Концепции сохранения, изучения и развития государственных и официальных языков Республики Саха (Якутия). [Decree of the Head of the Republic of Sakha (Yakutia) dated February 21, 2019 No. 383 "On approval of the Concept for the preservation, study and development of state and official languages of the Republic of Sakha (Yakutia)"]. www.sakha.gov.ru. Accessed: on 19 June 2020. 